\title{
QUANTITATIVE STUDY OF THE MYENTERIC PLEXUS OF THE STOMACH OF RATS WITH STREPTOZOTOCIN-INDUCED DIABETES
}

\author{
Cristina Elena Prado Teles Fregonesi', Marcílio Hubner de Miranda-Neto², \\ Sônia Lucy Molinari ${ }^{3}$, Jacqueline Nelisis Zanoni ${ }^{4}$
}

\begin{abstract}
The purpose of the present study was to investigate the morphological and quantitative alterations of the myenteric plexus neurons of the stomach of rats with streptozotocin-induced chronic diabetes and compare them to those of non-diabetic animals. Samples from the body of the stomach were used for wholemount preparations stained with NADH-diaphorase and for histological sections stained with hematoxylineosin. It was observed that diabetes cause a significant decrease on the number of neurons.
\end{abstract}

KEY WORDS: myenteric plexus, diabetes, rat.

\begin{abstract}
Estudo quantitativo do plexo mientérico do estômago de ratos com diabetes induzido por estreptozootocina

RESUMO - A proposta deste trabalho foi estudar as alterações morfológicas e quantitativas dos neurônios do plexo mientérico do estômago de ratos com diabetes induzido por estreptozootocina e estabelecer uma comparação com animais não diabéticos. Amostras do corpo do estômago foram submetidas a preparados de membrana corados pelo método da NADH-diaforase e a cortes histológicos corados por hematoxilinaeosina. Observou-se que o diabetes provoca significante redução no número de neurônios.
\end{abstract}

PALAVRAS-CHAVE: plexo mientérico, diabetes, rato.

Diabetes mellitus is a pathological condition in which several physiological abnormalities are observed, such as neuropathies that affect the central nervous system, the peripheral nerves and the autonomic nervous system ${ }^{1}$. Streptozotocin-induced diabetes causes a cycle of events in the nerve cells of the myenteric plexus that begins within one to three days, with the development of chromatolysis followed by regenerative changes over the next six weeks, with some continuous, albeit occasional, ganglionic degeneration ${ }^{2}$; changes in the innervation of the ileum and colon ${ }^{3}$ are reported, as well as a decrease on the neuronal activity ${ }^{4}$. Studies on streptozotocininduced diabetic rats have emphasized the alterations that occur in the small and large intestines. However, it should be remembered that alterations in the neurons of the myenteric plexus, in addition to changing intestinal peristalsis, can affect stomach motility, leading to dilation and retarded gastric emptying, interfering with the coordination between stomach and duodenum and impairing the digestive process ${ }^{5}$.

In a diabetic ketonuric Chinese hamsters examination of the gastrointestinal tract was observed that the animals had distention and atony of the stomach and intestines when compared with control animals ${ }^{6}$. In humans, among the clinical manifestations of autonomic neuropathy, there is motor impairment of the stomach, which can lead to anorexia, nausea, vomiting and persisting fullness, characterizing gastric debilitation ${ }^{1,5}$. It is also noteworthy that diabetic gastric atony is similar to that observed after vagotomy ${ }^{5}$.

Considering the extensive development of the myenteric plexus and its importance for the control of gastric and intestinal functions, and suspecting that diabetes may affect these neurons, in this way contributing to the gastric disturbances, we undertook the present study to determine the effects of streptozotocin-induced diabetes mellitus on the quan-

1'Professora Assistente do Departamento de Fisioterapia da Faculdade de Ciências e Tecnologia (FCT) da Universidade Estadual Paulista (UNESP), Campus de Presidente Prudente; ${ }^{2}$ Professor Titular do Departamento de Ciências Morfofisiológicas (DCM) da Universidade Estadual de Maringá (UEM); ${ }^{3}$ Professora Adjunto do DCM da UEM; ${ }^{4}$ Professora Assistente do DCM da UEM. Este estudo representa parte da Dissertação de Mestrado em Ciências Biológicas da primeira autora.

Received 12 May 2000, received in final form 8 September 2000. Accepted 16 september 2000.

Cristina Elena Prado Teles Fregonesi - Departamento de Fisioterapia - Faculdade de Ciências e Tecnologia, Universidade Estadual Paulista, Campus de Presidente Prudente - Rua Roberto Simonsen 305 - 19060-900 Presidente Prudente SP - Brasil. E-mail cristina@prudente.unesp.br 
titative aspects of the neurons of the myenteric plexus of the rat stomach.

\section{METHOD}

The study was conducted on 12 male rats (Rattus norvegicus), Wistar strain, aged 75 days and weighing about 250 g, from the Central Animal House of the State University of Maringá. The animals were maintained in accordance with the guidelines of the Committee on Care and Use of Laboratory Animals of the National Research Council of the $\mathrm{NIH}^{7}$.

The selected animals were divided into two groups: D2 - 5 animals sacrificed two months after diabetes induction, and C2 - 7 non-diabetic animals used as control. After being fasted for 14 hours in metabolic cages, each animal in group D2 received a single intravenous injection of 35 $\mathrm{mg} / \mathrm{kg}$ of streptozotocin.

On the day of the experiment, the animals were anesthetized with ethyl ether and subjected to laparotomy. A blood sample was obtained from the inferior vena cava and the stomach was removed. The diabetic condition was confirmed by the glucose oxidase method.

\section{Quantitative study of myenteric plexus neurons}

The stomachs of five animals from each group were washed in Krebs solution and next filled with the same solution with a catheter inserted through the pylorus. Then they were subjected to whole-mount preparations stained by the NADH-diaphorase method ${ }^{8}$.

Stomach segments from two animals in group C2 were subjected to routine histological techniques and stained with hematoxylin-eosin.

After staining with NADH-diaphorase the stomachs were opened and the regions of the fundus, corpus, pyloric antrus, and small and large curvatures were identified. Next, a $1-\mathrm{cm}$ sample of the corpus was removed. The sample ran from the small to the large gastric curvature. The samples were microdissected under a stereomicroscope, dehydrated in alcohol, cleared with xylene and placed between slides with synthetic resin (permount). Each of these samples was divided into three regions, and the neurons of the third near the small gastric curvature and of the third near the large gastric curvature were counted. The neurons of the intermediary third were not counted. Counts were carried out on five animals from each group. In each animal, 20 microscopic fields per region were counted, for a total of 40 fields per animal, using a microscope equipped with a $20 x$ objective lens. The half-neurons in a given field were considered and those of the subsequent field were discarded, alternately. The area of each field was $0.58 \mathrm{~mm}^{2}$, corresponding to a total area of $11.6 \mathrm{~mm}^{2}$ per region.

The material was photographed with an Olympus Bx50 microscope fitted with PM10 AK photography equipment.

\section{Statistical analysis}

We calculated the mean, standard error and coefficient of variation of the number of neurons found in each group, i.e., 100 fields per group on the small gastric curvature and 100 fields per group on the large gastric curvature. Student $t$-test was applied to compare the difference between means, with the level of significance set at $5 \%$.

\section{RESULTS}

When the catheter was introduced through the pylorus for injection of Krebs solution, a smaller resistance was observed in the diabetic animals than in the controls, suggesting a reduction of muscle tonus and pyloric dilation.

Histological sections from the corpus of the stomach of diabetic and control rats showed that the neurons of the myenteric plexus were predominantly found in ganglia located between the circular and the longitudinal layers of the muscular tunica (Fig 1). These ganglia were organized in networks spread all over the region under study (Figs 2, 3, 4 and 5). When comparing the observations made on the small gastric curvature (Figs 2 and 4) with those near the large gastric curvature (Figs 3 and 5) we observed that the ganglia were more numerous and had more neurons near the former. The nucleus was generally eccentric, and few neurons with a central nucleus were present.

In the control group we counted 7854 9917 neurons $/ 11.6 \mathrm{~mm}^{2}$ near the small gastric curvature and $1664 \pm 358 / 11.6 \mathrm{~mm}^{2}$ near the large gastric curvature, as opposed to $5269 \pm 390$ neurons $/ 11.6 \mathrm{~mm}^{2}$ and $1279 \pm$ $334 / 11.6 \mathrm{~mm}^{2}$ for the diabetic group, respectively.

Student $t$-test showed a significant difference in the mean number of neurons on the small gastric curvature between the two groups, with $t=5.8$ (critical value $=2.31, p=0.007319$ ). On the large gastric curvature this difference did not attain significance at the $5 \%$ level, with $t=1.76$ (critical value $=2.31, p=0.008835$ ).

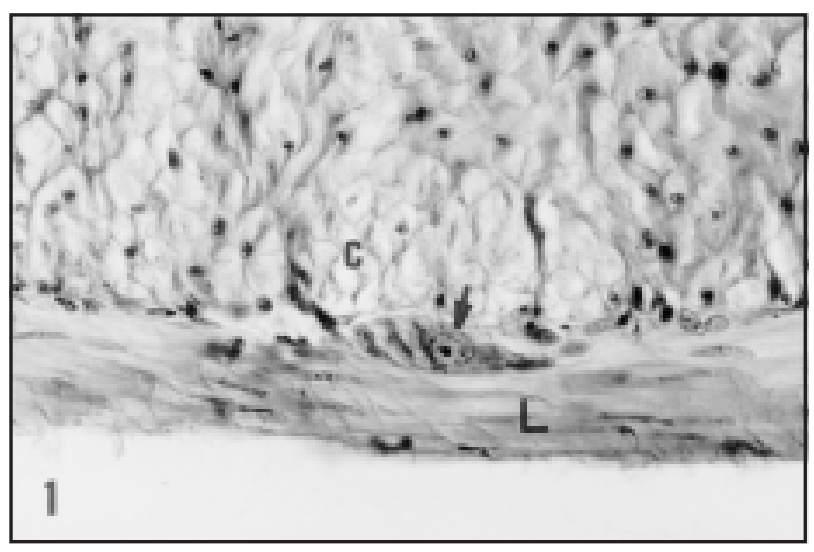

Fig 1. Longitudinal section ( $6 \mu \mathrm{m})$ of the corpus of the rat stomach showing a myenteric plexus neurons (arrow) in a ganglion located between the circular (C) and longitudinal (L) muscle layers. Hematoxylin-eosin, 481X. Green filter. 


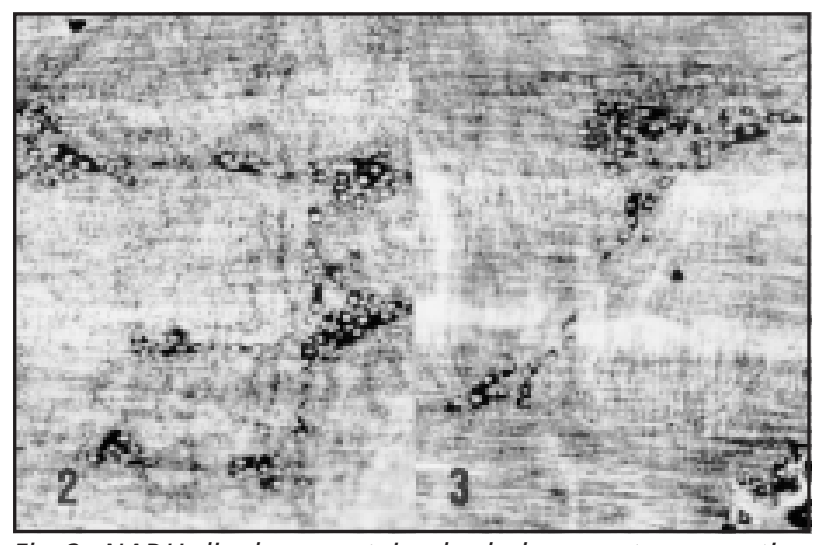

Fig 2. NADH-diaphorase-stained whole-mount preparation showing the arrangement of the myenteric plexus ganglia near the small curvature of the stomach from a rat from the control group. 91X. Green filter. Fig 3. NADH-diaphorase-stained wholemount preparation showing the arrangement of the myenteric plexus ganglia near the large curvature of the stomach of a rat from the control group. $91 X$. Green filter.

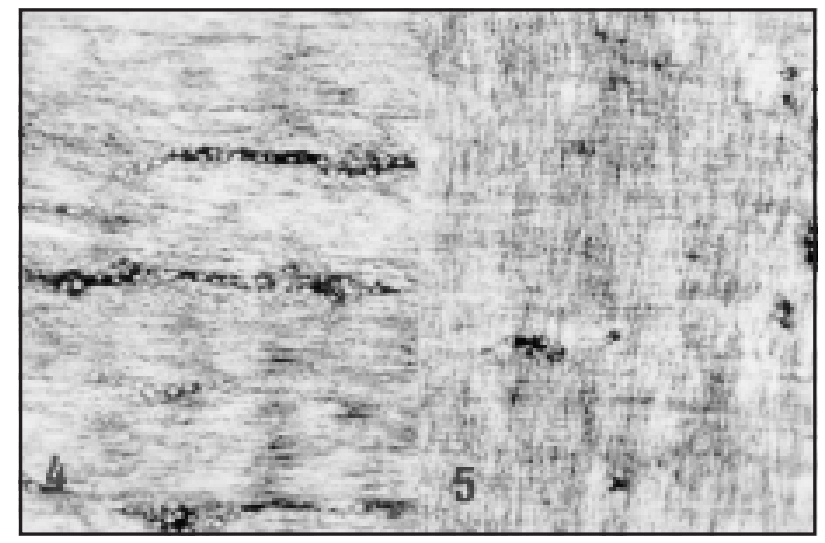

Fig 4. NADH-diaphorase-stained whole-mount preparation showing the arrangement of the myenteric plexus ganglia near the small curvature of the stomach of a rat from the diabetic group. 91X. Green filter. Fig 5. NADH-diaphorase-stained wholemount preparation showing the arrangement of the myenteric plexus ganglia near the large curvature of the stomach of a rat from the diabetic group. 91X. Green filter.

Table 1. Neuron incidence found in control and diabetic group animals in a $11.6 \mathrm{~mm}^{2}$ area in the small and large curvature.

\begin{tabular}{lcccc}
\hline & \multicolumn{2}{c}{ Small curvature } & \multicolumn{2}{c}{ Large curvature } \\
$\mathrm{N}^{\circ}$ & Control & Diabetic & Control & Diabetic \\
\hline 1 & 7743 & 4827 & 1331 & 962 \\
2 & 6495 & 5544 & 1661 & 1172 \\
3 & 8127 & 5172 & 2269 & 1770 \\
4 & 9050 & 5018 & 1524 & 1032 \\
5 & 7854 & 5784 & 1535 & 1458 \\
Total & 39269 & 26345 & 8320 & 6394 \\
Average & 7854 & 5269 & 1664 & 1279 \\
CV & 11.68 & 7.40 & 21.51 & 26.11 \\
S & 917 & 390 & 358 & 334 \\
p & & 0.007319 & & 0.008835 \\
\hline
\end{tabular}

$\mathrm{CV}$, coefficient of variation; S, standard deviation.

\section{DISCUSSION}

The present results demonstrate that streptozotocin-induced diabetes does not interfere with the clustering of the neurons in ganglia in the myenteric plexus of the stomach of rats, since the ganglia of diabetic animals showed characteristics similar to those of the control animals and to those described by other authors ${ }^{9,10}$.

Nevertheless, we observed that the myenteric ganglia of diabetic animals generally were of smaller dimensions, a fact possibly related to the reduction of the total number of neurons. When analyzing the mean neuronal density of the corpus of the stomach near the small gastric curvature, we observed a statistically significant decrease in neuron number, whereas the decrease observed near the large gastric curvature was not statistically significant. Possibly the absence of a significant difference in mean neuronal number for the large gastric curvature is related to the smaller density of neurons and the larger heterogeneity of their distribution when compared with the small gastric curvature; nevertheless, there was an undeniable neuronal decrease in the corpus of the stomach of diabetic rats. Some authors ${ }^{11,12}$ observed a neuronal decrease in the cecum and duodenum, respectively, of rats with streptozotocininduced diabetes. Conversely, other authors ${ }^{9}$ did not find a reduction in neuron number in the proximal colon of rats under the same experimental conditions. Such divergences have been explained by authors ${ }^{13}$ who stated that streptozotocin-induced diabetes has a differential effect on the various rats intestinal regions, with the distal colon being the last to be affected. 
Given that the neurons of the myenteric plexus, among other functions, control gastric motility and the muscular tonus of the stomach, we may assume that their decreased density in diabetic animals is one of the major causes of the abnormal gastric motility, distention and gastric atony observed in diabetic hamsters ${ }^{6}$ and of the gastric stasis observed in humans ${ }^{5}$. Radiological evidence of gastric retention has been reported for diabetic humans and was found to be related to diabetic autonomic neuropathy ${ }^{14}$. Disturbances of the motor activity of the intestine of diabetic rats were also reported ${ }^{15}$. The cited authors attribute these manifestations to the decreased density of myenteric neurons.

The loss of myenteric neurons, either sensory or motor, implies the reduction of innervation, altering the local control of sensitivity and motility.

The literature demonstrates that, in addition to the alterations of innervation related to the enteric neurons and their nerve fibers, there are alterations in the nerve fibers from other levels, such as paraand pre-vertebral ganglia and the central nervous system itself, since the metabolic alterations caused by diabetes lead to hyperglycemia, increasing the intracellular levels of glucose in insulin-independent tissues, including neurons and blood vessels. The excess glucose on the myelin sheath increases the production of fructose as a consequence of the increase in the amount of sorbitol, resulting in edema and rupture of the sheath and interrupting the conduction of nerve impulses ${ }^{16,17}$.

Research has provided evidence that the reduction of myoinositol results in reduced phosphoinositide metabolism, decreasing diacylglycerol and consequently decreasing the activation of protein kinase $\mathrm{C}$ and the membrane excitability of the nerve cells by altering $\mathrm{Na}^{+} / \mathrm{K}^{+}$ATPase activity $17,18,19$; the resulting excess of intracellular $\mathrm{Na}^{+}$could then lead to cellular edema, rupture of the myelin sheath and interruption of nerve conductance.

Possibly the interruption of nerve conductance can often be the reason why the gastric alterations of diabetes are asymptomatic. It has been commented that atony, distention and gastric emptying are generally asymptomatic because of a possible denervation of afferent sensory fibers ${ }^{20}$. Other authors argue that when the symptoms are present they include anorexia, nausea, vomiting and persistent fullness ${ }^{1,5}$.

In the present study we observed pyloric distention in diabetic animals, as also reported by other authors ${ }^{14,21}$. These authors report that the investigation with conventional food in association with barium reveals dilation of the stomach, with impaired peristalsis and delayed gastric emptying in spite of the pyloric distention.

Possibly the reduced peristalsis, delayed gastric emptying and pyloric distention have as a common cause the damage to the smooth muscle innervation of the stomach wall related to the loss of myenteric neurons and their fibers (intrinsic innervation) and the degeneration of nerve fibers of extrinsic origin, both of them as a consequence of diabetes.

Based on the observations on the myenteric plexus of the corpus of the stomach of rats, we conclude that in streptozotocin-induced diabetes animals the number of neurons is reduced to a significant extent on the small gastric curvature.

\section{REFERENCES}

1. Hosking DJ, Bennet T, Hampton JR. Diabetic autonomic neuropathy. Diabetes 1978;27:1043-1055.

2. Monckton G, Pehowich E. Autonomic neuropathy in the streptozotocin diabetic rat. Can J Neurol Sci 1980;7:142-153.

3. Lincoln J, Bokor JT, Crowe R, Griffith SG, Haven AJ, Burnstock G. Myenteric plexus in streptozotocin-treated rats: neurochemical and histochemical evidence for diabetic neuropathy in the gut. Gastroenterology 1984;86:654-661

4. Kniel PC, Junker U, Perrin IV, Bestetti GE, Rossi GL.Varied effects of experimental diabetes on the autonomic nervous system of the rat. Lab. Invest. 1986;54:523-530

5. Campbell IW, Heading RC, Tothill P, Buist TAS, Ewing DJ, Clarke BF. Gastric emptying in diabetic autonomic neuropathy. Gut 1977; 18:462-467.

6. Diani AR, Grogan DM, Yates ME, Risinger DL, Gerritsen GC. Radiologic abnormalities and autonomic neuropathology in the digestive tract of the ketonuric diabetic Chinese hamster. Diabetologia 1979;17:33-40.

7. www.nap.edu/readingroom/books/labraps/chaps.htm.

8. Gabella G. Detection of nerve cells by a histochemical technique. Experientia 1969;25:218-219.

9. Romano EB, Miranda-Neto MH, Cardoso RCS. Preliminary investigation about the effects of streptozotocin-induced chronic diabetes on the nerve cell number and size of myenteric ganglia in rat colon. Rev Chil Anat 1996;14:139-145.

10. Hernandes L. Estudo morfológico da mucosa e corpo celular dos neurônios do plexo mientérico do íleo de ratos com diabetes mellitus induzido por estreptozootocina. Tese de Mestrado, Universidade Estadual de Maringá. Maringá, 1994.

11. Zanoni JN, Miranda-Neto MH, Bazotte RB, Souza RR. Morphological and quantitative analysis of the neurons of the myenteric plexus of the cecum of streptozotocin-induced diabetics rats. Arq Neropsiquiatr 1997; 55:696-702.

12. Buttow NC, Miranda-Neto MH, Bazotte RB. Morphological and quantitative study of the myenteric plexus of the duodenum of streptozotocin-induced diabetic rats. Arq Gastroenterol 1997:34:34-42.

13. Belai A, Lincoln J, Milner P, Burnstock G. Differential effect of streptozotocin-induced diabetes on the innervation of the ileun and distal colon. Gastroenterology 1991;100:1024-1032.

14. Feldman M, Schiller LR. Disorders of gastrointestinal motility associated with diabetes mellitus. Annals of Internal Medicine 1983;98:378-384.

15. Karakida T, Ito S, Homma S. In vitro motor activity of intestinal segments of streptozotocin diabetic rats. J Auton Nerv Syst 1989;26:43-50.

16. Clements RS Jr. Diabetic neuropathy: new concepts of its etiology. Diabetes 1979;28:604-611.

17. Cotran RS, Kumar V, Robbins SL, Schoen FJ. Robbins patologia estrutural e funcional. 5.Ed. Melgaço ALS, Taranto G, Vasconcellos GS, et al.. Rio de Janeiro: Guanabara Koogan, 1996:816-830.

18. Alberts B, Bray D, Lewis J, Ralf M, Roberts K, Watson JD. Molecular biology of the cell. 3.Ed. New York: Garland, 1994: 745-749.

19. Lehninger AL, Nelson DL, Cox MM. Princípios de bioquímica. 2.Ed. Simões AA, Lodi WRN. São Paulo: Sarvier, 1995:570-585.

20. Clarke BF, Ewing DJ, Campbell IW. Diabetic autonomic neuropathy. Diabetologia 1979;17:195-212.

21. Zitomer BR, Gramm HF, Kozak GP. Gastric neuropathy in diabetes mellitus: clinical and radiologic observations. Metabolism 1968; 17:199-211. 